\title{
Memories of traditional rice cultivation by descendants of Indian contract laborers in Suriname
}

\section{Melissa Ramdayal}

Leiden University

\section{Harro Maat}

Wageningen University https://orcid.org/0000-0001-7338-7910

Tinde van Andel ( $\boldsymbol{\nabla}$ tinde.vanandel@naturalis.nl )

Naturalis Biodiversity Center https://orcid.org/0000-0002-4951-1894

\section{Research Article}

Keywords: indentured labor, Indian diaspora, landraces, Maroons, oral history, Oryza sativa

Posted Date: December 8th, 2020

DOI: https://doi.org/10.21203/rs.3.rs-119658/v1

License: (c) (1) This work is licensed under a Creative Commons Attribution 4.0 International License.

Read Full License 


\section{Abstract}

Some 35,000 indentured laborers from India were recruited to work on plantations in Suriname after 1863. Many of them started to grow rice for their subsistence, but were stimulated to replace their traditional landraces for improved cultivars. Few Hindostani smallholders still cultivate rice today, and little is known on their varieties or motivations to continue or abandon this crop. We interviewed 30 persons currently or formerly involved in small-scale Hindostani rice farming, collected rice varieties and documented people's personal memories and motivation for rice cultivation. In the historic literature, ca. 16 varieties were mentioned to be grown by Indian contract laborers, of which nine were remembered by our interviewees. We recorded 55 variety names, their agronomical and culinary characteristics, geographic origin, and (former) cultivation localities. Most active smallholders grew cultivars developed after 2000, but one landrace (Raymoen) and some old cultivars developed in the 1930-1950s (Rexora and Dima) were still grown for fodder, although heavily adulterated with weedy rice. Maroon farmers in the interior, however, cultivated several varieties of 'coolie rice' that they obtained from Hindostani farmers in the past, although this needs to be confirmed by molecular research. Small-scale rice farming in Suriname is declining due to competition with large-scale cultivators, urbanization, better education prospects and migration to the Netherlands. The vivid memories of the (former) rice farmers on traditional practices, gender-based labor division and how rice farming is integrated in the system of beliefs, as well as the few remaining varieties that potentially originated in India, deserve to be better safeguarded and shared with the public than they are today.

\section{Introduction}

From 1838 to 1917, over half a million citizens from the former British India were recruited as indentured workers on Caribbean sugarcane plantations to address the labor shortage following the abolition of slavery. These movements of people, their impact on the plantation economy and the social and cultural dynamics in the Caribbean are well documented (Gowricharn 2013; Fokken 2018). However, less is known about the production of food for their own subsistence, although colonial agricultural reports mention the many traditional crops that the Asian contract laborers brought from their home countries and cultivated in their small fields and house yards (Williams and Williams 1951; Ostendorf 1962).

In Suriname, the first 'British Indians' entered via Guyana in 1868, just five years after slavery was abolished in 1863. A ship named Lalla Rookh arrived in Paramaribo on 5 June 1873, carrying 339 immigrants who had boarded in Calcutta, but originally came from the current regions of Uttar Pradesh, Uttarakhand and Bihar in northern India. In 1916, when migration from India came to an end, Suriname had received ca. 35,000 East Indians, who refer to themselves today as 'Hindustanis' (Gowricharn 2013), but were indicated in the past as 'koelies' (coolies) or kantráki, the Sranantongo word for contract laborers (Fokken 2018). Between 1890 and 1940, the Dutch also recruited 32,956 Javanese from the former Dutch East Indies (now Indonesia) to work in Suriname (Hoefte 1998; Gowricharn 2013). Most Asian labourers were recruited on the basis of a three-year contract. Working conditions on the plantations were harsh and payment was low, so when their contract ended, few enlisted for a second contract, and about one 
third returned to their home countries. The majority continued as smallholder farmers, initially squatting on land but later stimulated by the colonial government through a land allocation regulation (Boonacker 1933; Maat and van Andel 2018). From about 1910, the area farmed by smallholders was larger than that of the plantation sector (Hoefte 1998).

Most Asian immigrants had been farmers before they were shipped to Suriname. The Dutch agronomists Boonacker and Dost (1907) observed that 'most of the British Indians were growing rice as a staple crop'. In spite of the 'very primitive and extremely flawed manner in which these people cultivate these crops', Boonacker (1933: 342) was surprised to see that the rice yields (all Asian rice, Oryza sativa L.) obtained from these smallholder fields could meet Suriname's domestic demand. He foresaw great opportunities for mechanized rice farming and export for the colony, but then the traditional, 'non-commercial' rice varieties should be replaced by cultivars suitable for machine-harvesting: ripening evenly, in less than five months, with uniform grains, short stems to prevent lodging, and non-shattering panicles.

In neighboring Guyana, initiatives towards commercial rice farming started much earlier: in 1895, the first rice mill was established in Georgetown, but failed as the paddy supplied by East Indian farmers consisted of many different varieties and grain sizes (Potter 1998). Around 1908, a series of smaller mills were operating in the coastal villages and agricultural instructors were sent out to teach farmers to become more commercially oriented. By advancing them cash and goods, the rice mill owners drew the farmers into debt again and forced them to abandon their traditional varieties as they paid higher prices for uniform 'pure' seed (Potter 1998). In 1927, traditional East Indian rice varieties were tested for their suitability for large-scale mechanical cultivation in the Experimental Station in Georgetown. Although they were generally characterized as inferior, infested with weedy red rice and mixed with odd-looking types, some were selected as promising material to breed new cultivars by Codd and Peterkin (1933). Their report is one of the few early sources that provides an overview of traditional East Indian rice varieties in the early 20 th century.

From 1904 onwards, agronomists in Suriname imported 40 to 50 rice varieties from Demerara (Guyana), India, Java and French Indochina (Vietnam) and planted them in experimental field trials in the coastal districts (Drent 1908; Brandon 1933; Stahel 1933). Although most varieties did not perform well on the heavy clay soils, some reproduced successfully and were handed out to farmers, together with newly developed commercial cultivars that were based on imported varieties (Stahel 1933). Smallholders from Indian origin had different preferences than those from Java (Drent 1908). The Javanese farmers generally grew several sticky rice varieties. Popular Hindustani varieties were Moetmoeria, Fini tere, Djerehi, and Skrivimankoti, the latter considered to be the most interesting commercial variety (Stahel 1933).

After World War II, large areas of the coastal wetlands of Nickerie were transformed into commercial rice fields, operated by the state-sponsored SML (Stichting Machinale Landbouw) and the Van Dijk company. The scheme was run in the basis of contracts with mostly Hindustani farmers (Ostendorf, 1962). After 1965, the semi-dwarf varieties from the International Rice Research Institute (IRRI) were included in the 
breeding program. After independence in 1975, the Surinamese National Rice Institute (SNRI/ADRON) continued to breed modern high-yielding cultivars for the rice sector (Maat and Van Andel 2018, SNRI/ADRON, 2010). In 2014, over 35,000 hectares were cultivated by farms of 12 hectares or more, whereas smaller farms totaled to about 26,000 hectares, together producing 275,000 tons of which about 105,000 tons were exported (http://suriname-rice.com/rice-statistics/). Although almost every rice farmer in coastal Suriname produces for national and international markets, there is quite some variation in farm size, cropping patterns and uses of rice. Hardly any research has been done on the rice varieties that farmers cultivate today, and whether they still use the older landraces. The latest studies on this are from the1960s (e.g., De Wit, 1960).

Landraces are farmer-developed, traditional crop varieties that are genetically variable and thus adaptable to local climate and soil conditions and cultural preferences (Zeven 1998; McCouch 2004). Thousands of rice landraces were grown before the advent of the Green Revolution, but the modernization of agriculture resulted in a dominance of high-yielding cultivars that require chemical fertilizers and pesticides, controlled water supply and mechanization. Since the 1950s, a significant proportion of rice landraces has disappeared from farmer's fields worldwide, resulting in severe genetic erosion of rice (Deb 2019). Traditional landraces often show pest resistance and adaptations towards marginal environments, and are therefore considered as an untapped genetic resource for breeding new cultivars resilient to future challenges (McCouch 2004; Wang et al. 2018). Apart from their key role in local food security and the preservation of cultural heritage (IPBES 2019), landraces also reveal past patterns of human migration, trade and contacts with outsiders (Sharif et al. 2020).

The turbulent migration history and a high cultural diversity of Suriname is likely to be reflected in the traditional crop varieties grown by small farmers in the country. In 2012, a black-seeded variety of Oryza sativa, known as 'Ketan iran' was observed in a wetland field near the former plantation Reijnsdorp (Commewijne district). The farmer, an aged Javanese lady, said was the only one who still planted this once popular type of dark sticky rice, which she used for food and ceremonies (Heilbron 2012). According to Stahel (1933), sticky Javanese varieties entered Suriname between 1907 and 1911, but were gradually replaced by other varieties in 1929. Recently, the likely origin of a landrace of African rice (O. glaberrima Steud.), grown by Maroons, descendants of enslaved Africans who escaped from the plantations and settled into the forested interior, was traced back to western Ivory Coast (van Andel 2010; van Andel et al. 2016). These findings indicate that rice landraces can reveal unwritten histories of crop diffusion over centuries and the contribution of the diverse waves of migrants to the agricultural diversity and innovation in Suriname.

The aim of this research was to document the rice varieties grown currently or in the recent past by (descendants of) Hindustani smallholders in coastal Suriname, their origin, morphological and agronomic characters, local uses and cultural and spiritual relevance. Given the rapid decline in smallscale rice cultivation in coastal Suriname in the past 40 years (Roosken 2010), we wanted to know why people continued or abandoned rice farming and what aspects of traditional practices still survived. We focused specifically on indications of rice exchange between Hindostani farmers and other ethnic groups. 
We hope that this study contributes to the preservation of oral and agricultural history among descendants of East Indian indentured laborers.

\title{
Material And Methods
}

\author{
Inventory of ancient Asian landraces
}

From historic literature and labels of rice specimens in the herbarium and Economic Botany collection of Naturalis Biodiversity Center $(L)$ in Leiden, the Netherlands, we compiled a database of names for Asian rice varieties that were mentioned as being grown by East Indian contract laborers and small-scale farmers in Guyana and Suriname between 1868 and the present (Supplementary Table 1). We also included names of several early rice cultivars developed by agricultural institutes and traditional Javanese, Maroon and Creole landraces that were known to be distributed among East Indian farmers or grown in experimental plots with hired East Indian labor, which probably facilitated adaption of these varieties by these farmers. We searched the Genesys platform (www.genesys-pgr.org) to see whether germplasm for these variety names was conserved in gene banks. We photographed specimens of historic varieties kept at in the Naturalis herbarium, and collected a few grains of each variety name. We glued husked and dehusked seeds of these historic varieties under transparent tape on white paper, and placed these in transparent folders in a ring binder. This 'rice book' was taken into the field to facilitate communication with rice farmers and their descendants in Suriname. Throughout this paper, we use the Surinamese term 'padi' for husked rice, different from the English term paddy, indicating a wetland rice field.

\section{Field interviews}

In the Netherlands, we interviewed the managers of two religious Hindu shops in The Hague and Zoetermeer on ritual uses of rice and possible contacts of rice farmers in Suriname. Fieldwork in Suriname was carried out between 27 September and 22 November 2018. After obtaining prior informed consent, semi-structured interviews were held with (family members of) currently active and former smallscale rice farmers of East Indian descend, and people of other ethnicities (Maroon, Creole, Javanese) who were somehow involved in the cultivation of East Indian rice varieties or had been active on rice farms owned by Hindostani in the past. Participants were recruited by means of snowball sampling and previous contacts with family members of (former) rice farmers living in the Netherlands. Small-scale farmers were defined has having (had) rice fields smaller than 10 ha. We did not interview employees of the large, industrial rice farms that presently are operative around Nickerie. Following the suggestions of our Hindostani informants on where to find traditional varieties, we also interviewed one Javanese and several Maroon farmers.

Our questionnaire focused on the varieties grown (now or in the past) by small-scale rice entrepreneurs, their local names and meanings, agronomic qualities, and origin of the seed stock. We also included 
questions on traditional and current farming methods, cultural and spiritual aspects of rice cultivation, people's personal memories of rice farming in the past, as well as their motivations to continue or abandon this practice (Supplementary Table 2). All interviews were conducted by the first author and held in Dutch and Sranantongo (Surinamese Creole), or, with the help of translators, in Sarnami (language of mixed Indian origin spoken by Hindostani in Suriname), or in Aucan and Saramaccan (Maroon languages). The interviews with Maroon farmers focused on rice varieties exchanged with Hindostani farmers in the past. Some parts of interviews were recorded as sound clip and/or videotape, a few of these recordings were published on YouTube.

Data from interviews were entered in a spreadsheet to analyze responses. A separate spreadsheet was created with rice varieties mentioned during the interviews and their associated information. To verify the spelling and scientific names of the local names mentioned by the interviewees, we consulted Van Andel and Ruysschaert (2011) for plants, Fish Base (www.fishbase.se) for fish, and the online databases of the Summer Institute of Linguistics (www.suriname-languages.sil.org/index.html) for terms in the Sranantongo, Aucan, Saramaccan and Sarnami languages.

\section{Rice collections}

Rice seeds and inflorescences were collected from people's field and kitchens in paper envelopes and deposited at the SNRI/ADRON in Nickerie and Naturalis. Macro-photographs were made from the husked seeds and dehusked grains of all different rice varieties and off-types. Morphological characteristics of each variety (length and width, husk color, presence and length of awns, etc.) were documented and entered in the spreadsheet. A few grains of each variety were germinated on wet tissue paper to obtain fresh leaf material for DNA extraction, to be used for future genetic research. In Paramaribo, the National Herbarium Suriname (BBS) was consulted to verify whether specimens of traditional East Indian rice varieties had been preserved in Suriname. The database and collections of the SNRI/ADRON were consulted to find out for which traditional Asian varieties the germplasm had been safely stored.

\section{Results}

Interview participants

In total, we interviewed 41 people (16 males, 25 females), including 26 of Hindostani descend, 11 Maroons, one of Javanese origin, and three of mixed ethnicity. Participants resided in the districts of Paramaribo, Wanica, Commewijne, Nickerie, Saramacca, Marowijne and the Maroon village of Jawjaw in the Sipaliwini district (Fig. 1). The Maroon participants (1 male, 10 females). included ten active rice farmers: four Aucans in the villages of Santigron (Wanica district), Tamanredjo and Macreabo km 54 (Commewijne), km 57,5 (Marowijne) and six Saramaccan women and one male involved in the promotion of traditional rice cultivation in Jaw Jaw.

The 30 non-Maroon participants were all somehow involved in Hindostani rice farming: four were current vendors of padi (two in the Netherlands, two in Suriname), five were active rice cultivators, ten were 
former traditional rice farmers, nine used to work on the rice farms of their Hindostani family or friends, one used to operate a rice mill, one was a staff member of the Lalla Rookh museum on the history of East Indian immigration in Paramaribo and one was the director of the Nickerie department of the Ministry of Agriculture, Livestock and Fisheries (LVV). The age of the participants varied between 28 and 85 , with an average of 61 years. Apart from rice farming, they had a variety of occupations, such as bus driver, antiquarian, rice miller, board member of the Surinamese padi farmer association, or sociologist at the SNRI/ADRON. During the interviews, some participants were joined by other household members who also provided information, so the information obtained during a single interview often represented the knowledge of more than one person.

Historic rice varieties

No systematic inventories have ever been made on traditional rice landraces cultivated by East Indian or Javanese farmers in the Guianas. Data on these varieties was scattered among historical agricultural reports, without references to herbarium or seed collections (Boonacker and Drost 1907; Brandon 1933; Stahel 1933; Codd and Peterkin 1933; de Wit 1960). Still, we retrieved information on ca. 16 rice varieties, with in total 24 vernacular names, as some varieties had names in Sranantongo and Sarnami (Supplementary Table 1)

Although the Naturalis herbarium has the largest collection of specimens from the Guianas worldwide, no herbarium vouchers or seed material were found for the historic varieties Garika Suama Vari and Kristna Kata Kulu, recorded only for Guyana (Codd and Peterkin, 1933) and Fini tere, first mentioned by De Surinaamsche Courant (Anonymous 1871) and last by Ostendorf (1962). None of the interviewees mentioned these variety names, so their names must have been forgotten and the varieties have either been lost or are still cultivated under other names. For the varieties Anaki tapoen, Mutmuria, Ramcajara and Sutra dhân no herbarium material could be located either. Of these four varieties, farmers only remembered Mutmuria, which was said to be still grown occasionally in the Saramacca district for both human consumption and chicken food. The available germplasm for Mutmuria also originated from Suriname (Supplementary Table 1). Several of the varieties that were planted in the experimental station in Paramaribo had been preserved as bundles of panicles wrapped in paper or stored in wooden boxes in the Economic Botany collection of Naturalis (e.g., Padi Nickerie, Blue Rose and Demerara Creole). Farmers still remembered several of these historic varieties, such as Padi Nickerie, Padi Tjina, Blue Rose and Demerara Creole, of which the latter was still said to be cultivated, but no details of the location were known, so no seeds could be collected. Although most of the Hindostani we interviewed had abandoned rice farming, they still mentioned many varieties that they had grown in the past or seen on other people's fields. We compiled a list of 55 variety names, with information on their agronomically and culinary characteristics, origin, former and current collection localities (Supplementary Table 3). Of these 55 names, nine were also mentioned in the historic literature (Supplementary Table 1). We were able to collect only four different varieties on rice fields of Hindostani farmers. The Maroon farmers mentioned ca. 18 additional names for rice varieties, 10 of which were collected. 
One of the most famous historic landraces from Suriname was Skrifimankoti (also spelled as Srivimankoti), of which the name literally means 'writer's coat', referring for mysterious reasons to the jacket of a supervisor. Imported in 1890 by East Indian immigrants, it became the most important wetland variety in Suriname, suitable for the heavy clay soils in the coastal plains (Stahel 1933; 1944). In 1904, it already had the highest quality and yield, and was still grown by smallholders in Suriname in the early 1960s (de Wit 1960; Ostendorf 1962). Skrifimankoti was unsuitable for mechanized harvesting because of its tall stems and tendency to lodge (Stahel 1944; De Wit 1960). It had a growth season of six months, and a high value on the global market due to its 'Patna-type appearance', referring to its white, elongated and thin grains (De Wit 1960; Ostendorf 1962). Skrifimankoti was considered to be the same as the Indian variety Patarka dhan (Stahel 1944), and quite similar to the Demerara Creole from Guyana. Observers also compared it to Carolina Gold from the US. In the 1900s, seeds were sent to breeding stations in the US and Java (Maat 2001), where it was distributed to farmers (Maat 2001). This landrace was the genomic base for many modern cultivars employed in the Surinamese mechanical rice cultivation today (Maat and Van Andel 2018).

Of the 30 interviewees that were (once) involved in Hindostani rice farming, ten remembered Skrifimankoti. They confirmed that it took more than five months to ripen, but the quality of the rice was good and the yield was high. They remembered it as the 'miracle variety', but it lodged easily, especially when not harvested on time. According to our participants, Patarka dhan ('thin rice') was different from Skrifimankoti: it had a four-month growth season, high yield, nutritious grains, and a good resistance to pests and diseases. It lodged easily and was harvested by hand with a sickle. Demerara Creole had shorter grains than Skrifimankoti and came from Guyana. This was confirmed by the historic seed collections from 1932 in Naturalis, of which 'Padi Demerara' (L.2110084), had brown-tipped grains that were somewhat shorter than 'Skrivimankoti' (L.2110089). Living seeds of Skrifimankoti are preserved at the SNRI/ADRON germplasm bank and represent one of the few Indian rice landraces from the Guianas that are still preserved today (Supplementary Table 1).

Most interviewees knew the difference between old landraces and modern cultivars. As former rice farmer Mrs. Chitrawatie (60, from Saramacca) explained: "You could recognize old varieties by their height: they were often 1.5-meter tall, the modern varieties are shorter. Nobody grows these old races anymore I think [...]." The farmers remembered that the high plants lodged easily when it was almost time to harvest, which resulted in a loss of yield.

Landraces that were said to be grown before the mechanization and harvested and peeled by hand were the sticky Javanese Ketan varieties, Shifonia, Barbaman and Padi oeloe (Supplementary Table 3). Typically, some Hindostani farmers also cultivated Ketan rice in the past. The yield was exchanged with Javanese women who would process it into sweet rice dishes for the Hindostani families. Barbaman ('bearded man') and Padi oeloe ('worm rice') had long awns, which suggests they were not suitable for mechanized cultivation. Awns protect grasses from predation by animals, and aid seed dispersal by clinging to animal fur (Hua et al. 2015). They are also a nuisance during mechanical seed processing and storage, so from the 1960s, modern rice cultivars in Suriname were awnless (de Wit 1960). 
The only landrace that was still cultivated by our participants in 2018 was Raymoen (Fig. 2A), grown by one farmer in Saramacca, and abandoned by five other participants (Supplementary Table 3). Also known as Ramoen or Ramona, it was probably a landrace of Javanese origin, with tall stems (ca. 1,5 m), 'good, nutritious padi, soft when cooked', and did not have any diseases, so no agrochemicals were needed. The negative aspects of Raymoen were the tendency to lodge, the variability of the gains, and low yields with 'hard seeds' when there was wind and rain during harvest. It was used for home consumption and chicken feed. Typically, one farmer said it was 'the same as Mutmuria', but as we have no specimens for the latter landrace, morphological comparison was impossible.

The best-known historic variety (remembered by 14 Hindostani and the single Javanese participant) was Rexora, also known as Bergi (hill) Lexora. This non-lodging, 'Patna'-type upland cultivar was imported in the spring of 1932 from Louisiana (US) and planted in experimental trials in Paramaribo to see whether it was suitable to replace Skrifımankoti on poor, better drained soils (Stahel 1932). Rexora was sent out in 1936 to the Saramaccan Maroons village of Ganzee (Stahel 1944). Although none of the Hindostani (former) farmers we interviewed still cultivated it, many of them praised this cultivar for its high yield, good taste, nutritious value and resistance against diseases: it did not need any pesticides and thrived on drier grounds. The Rexora cultivar was abandoned by commercial rice farms in the 1960 s after a severe attack of Cercospora disease (Sanderson 1962). However, the Aucan women we interviewed in the Commewijne and Marowijne district and the Saramaccan women in the Sipaliwini district still actively cultivated an elongated upland rice variety that was known as Alekisola or White Sola. This '(Aleki-) sola, genetically quite distinct from traditional Maroon varieties (Van Andel et al. 2019), is likely to be the locally adapted progeny of the 1960 cultivar Rexora. It was also grown by Aucans along the Marowijne and Lawa rivers in 2017 (Van Andel et al. 2019) and along the Tapanahoni river in 2013 (Naturalis L.3928210). The 'Red Sola' rice represents different Maroon landraces that have no relation to Rexora (Van Andel et al. 2019).

Several of the other 43 varieties named during our interviews referred to old cultivars, that were said to be 'introduced by the Dutch' after the beginning of mechanized rice farming. Examples are Alupi, Apikalo, 81B and Holland (Supplementary Table 3), developed by SML in the 1950s and 1960s (Maat and Van Andel 2018). SML cultivars developed from the 1970s onwards often received names ending with -ni (after Nickerie), the seat of the breeding institute. The farmers had mixed feelings about the qualities of these early cultivars: some had 'good cooking quality' (Diwani, Alupi, Eloni, Dima, Holland), but others were lodging (Campochino, Holland, 81B), shattering (Dima) or remained hard when cooked (Camponi).

Fifteen (former) Hindustani farmers said Dima was a good cultivar, which was still occasionally cultivated in the polders of Wageningen (Nickerie district). Developed from Skrifımankoti in 1953 for mechanized harvesting and named after the rice breeding pioneers Van Dijk and Mastenbroek, Dima had stiff straw to prevent lodging, and was considered far superior than other popular varieties at that time, such has Rexora, Bluebonnet and Skrivimankoti itself (De Wit 1960; Ostendorf 1962). We collected specimens of Dima from a 66-year old Aucan Maroon farmer along the East-West highway in the Marowijne district (Fig. 2C). She said that Dima was also planted by her grandparents, who had obtained 
it from Hindostani farmers. In spite of its shattering panicles, this knee-high cultivar with elongated grains produced sweet rice when harvested and peeled by hand. Around 2005, ethnobotanist Bruce Hoffman (pers. comm.) also heard about a rice variety named Dima in Stonhuku, a Saramaccan village along the Gran Rio, deep in the interior of Suriname. An Aucan farmer in Marowijne said she previously also planted the 1963 cultivar Hollandia, which thrived on low and wet soil, just like Dima.

At least ten rice names mentioned during our interviews referred to (relatively) modern cultivars, with short growth seasons and many seeds per panicle, developed after 1995 by SNRI/ADRON or commercial companies like Manglie, Ini-Dia and Paloma. According to the farmers, the name of the cultivars referred to the number of days the plant took to ripen. The once popular cultivar 110, which had a heavy panicle with thick, long and yellowish seeds, and took 110 days from sowing to harvest, was said to have replaced Skrifimankoti. The cultivar DDB2 was developed in 2017 by SNRI/ADRON and named after Suriname's controversial ex-president Desi Delano Bouterse. According to our participants, DDB2 was susceptible to diseases, had weak stems that lodged easily, and implied high costs and little profit, which was confirmed by SNRI/ADRON (Debidien 2020). It was still grown by one of our participants in the Saramacca district for home consumption and the market. The modern cultivar 125 was grown in large quantities in Nickerie, but also susceptible to fungi (Mahabier 2007). The farmers we interviewed never used the latest cultivars developed by the SNRI/ADRON around 2010, such as Elitezaad ADRON-128.

\section{Seed sources}

Our respondents knew from their family history that the indentured labourers from India brought their own rice varieties, kept some of their harvested rice as seed stock to plant later on, and traded or bartered planting material within the Hindustani community. The different ethnicities (Hindostani, Javanese, Creoles, Maroons) lived (and still live) in separate areas, so the seed swaps were mostly done in the neighbourhood. Exchange in rice with other ethnic groups were rare events, but did take place occasionally, as was shown by the Javanese landraces grown by Hindostani farmers, and the Maroon farmers cultivating Dima and Holland. From the 1930s onwards, the crop breeding institutes started to distribute improved cultivars among farmers, and discouraged them to use their own seed stocks for sowing the next harvest. It became common to buy planting stock at specialized stores that sold modern cultivars developed by the breeding institutions (SML and later SNRI/ADRON). Still, several farmers used their homegrown rice as plant material, or experimented with unknown varieties obtained from other farmers. A 71-year old farmer recalled that once she saw a man carrying rice on the streets, and noticed that he had dropped some seeds. She picked them up, and her father planted them in his field in the Henaerpolder (Nickerie district). She remembered that it produced a very short rice plant, with a full, pale brown panicle, and they enjoyed eating it. This rice type, probably a commercial cultivar because of its short stems, was grown for years by this family and named Doerdjie (possibly referring to the Sarnami term for semolina (soedjie), see Supplementary Table 4).

During the last decades, the Ministry of Agriculture and Fisheries (LVV) and SNRI/ADRON have continued their efforts to convince farmers to buy registered seed of modern cultivars. It is prohibited by the 
Surinamese law to keep your own planting stock for the next season or sow 'illegal rice' that is not controlled by LVV or SNRI/ADRON, because contamination with other rice types damages the good reputation of the Surinamese long-grain export rice. Unknown pests, diseases and rice weeds enter the country with illegal rice, leading to decreasing yields and increasing costs for pesticides and herbicides (SNRI/ADRON 2017). However, some of the (former) rice farmers we interviewed said that in spite of their lower quality, rice cultivars from Guyana were becoming more popular, as they needed less agrochemicals. These anecdotes show that not all farmers buy certified (pure) seed stocks, but also maintain informal seed exchange networks.

Weedy rice

Our sample of 'Nickerie padi' grown for fodder contained grains that varied substantially in size, shape, colour and the presence of hairs and awns. When milled, a proportion of the grains were red. This fodder rice was heavily mixed with weedy rice, hybrids between Oryza sativa with wild rice (O. rufipogon Griff.), characterized by hairy and ridged husks, awns and red grains (Fig. 3). The fodder rice also contained seeds from rice weeds, such as Ischaemum rugosum Salisb. with inflorescences that looked like the segmented insect bodies. Hindustani farmers called the weedy rice 'lalya' (red in Sarnami) and recognized it in vegetative form by its tall stems and broad leaves. They would pull it out of their field, as it lodged easily when ripe and then dragged the commercial rice down as well. Weedy rice is quite hard to get rid of, since the seeds survive in the wet clay soils for years. To remove the red bran, farmers had to polish the rice more thoroughly. This led to less volume of rice and more fragile grains, which broke easily and sold for less. According to our participants, weedy rice was a greater problem in wet rice fields and mechanical rice farming systems than it was before in manual rice cultivation. Farmers who only grew rice for fodder (mostly chicked feed) did not mind the weedy rice in their fields. One farmer used to plant a six months upland variety named Moeng that was also a mixture of red and white grains. This fodder rice, sold for ca. $€ 5$ per $10 \mathrm{~kg}$ in Suriname, facilitates the spread of rice weeds in the coastal plains. Remarkably, some of this mixed rice ends up in ritual Hindu shops the Netherlands, where it is sold for a much higher price ( $€$ 4,95 for c. $250 \mathrm{gr}$ ) to be used during religious ceremonies (MMR1, Supplementary Table 3).

Historic Indian varieties on Maroon rice fields

Saramaccan rice farmers in Jawjaw cultivated several varieties named Koelie aleisi ('coolie rice'), which differed in husk color, pubescence and presence of awns (Fig. 4A-C). Some Maroon women said that these varieties were traded by their grandparents with Hindustani people or bought in the city several generations ago. In times when there was not enough seed left for sowing because of a bad harvest in the previous year, villagers planning to travel to Paramaribo were instructed to buy some padi (husked rice) on the market. Another variety of possible Indian origin was Watralanti ('waterland'), which had to be planted on lower, moist ground, just like the Koelie aleisi, which suggests both descend from wetland varieties (Fig. 4D). One interviewee said that she had 'seen Watralanti rice herself being planted by Hindustani farmers in Nickerie'. 
Herbarium collections of Watralanti rice were collected earlier in other Maroon rice fields (Supplementary Table 3; Van Andel et al. 2019). A Watralanti variety collected by Baumgart et al. (1998) in the Saramaccan village Nieuw Aurora had the second name Jarikaba (DMR 980029), which refers to a region in the coastal Saramacca district with East Indian and Javanese farmers. In the same area, they recorded the varieties Mboto Molia (DMR 980011) and Mbotomolia or Botombolie (DMR 980018), which were later deposited at the SNRI/ADRON collection and the US National Plant Germplasm collection

(Supplementary Table 1). According to Baumgart et al. (1998), these varieties represented Hindostani rice, and the name Mboto Molia/ Botombolie descended from the historic Indian landrace Mutmuria. A variety named Patalika (which resembles 'Patarka') was recorded around 2005 in Stonhuku (Bruce Hoffman, pers. comm.), but unfortunately no collections of photographs were made.

Buying seed stock is exceptional among Maroon rice farmers, as most varieties are handed down within the household from generation to generation or exchanged with extended family members during funerals (Price, 1993; Van Andel et al., 2019). The potential presence of East Indian rice varieties on Maroon farms indicates that occasional introductions of 'foreign' rice varieties have taken place in the past, and in some cases were successful. Trying out new varieties, however, is not something of the past. Andelia Boenakaba, a 65-year old Aucan rice farmer from Macreabo (Commewijne) recognized the historic cultivar 'Padi Nickerie Wageningen select' from our rice sample book. She said she once bought it at the central market in Paramaribo and sowed it in her field. A Saramaccan farmer in Jawjaw also said she bought husked padi at the same market, and was surprised to see that it grew into a dwarf rice plant. Our research indicates that both historic varieties and modern wetland cultivars have found their way to Maroon rice farms in the interior, facilitated by markets and experiments of curious farmers.

Current and past motivations for rice cultivation

The main reason for our interviewees to cultivate rice was home consumption: 17 of the 30 Hindostani participants had cultivated rice by hand for more than 30 years. When they were young, there were few other job opportunities outside agriculture. Before the development of mechanical rice farming, their families did not have enough money to buy rice in a store, and it was not even common that shops sold rice. It was essential to be self-sufficient and grow your own food. Rice was then and still is the staple food: the basis of many dishes eaten for breakfast, lunch and dinner. In the past, some people used home-grown, hand-milled rice to barter for products in grocery shops. Former rice farmer Mrs. ChotkanoeJhinkoe (70) from Wanica remembered that she traded "one kilogram of rice for one kilogram of salt or sugar at our local store". If there was more padi in stock than needed for home consumption, the surplus was stored in a shed behind the house and sold in the husk to merchants. With the money earned, the farmers could buy other victuals. "We sold one bale of padi for three Surinamese dollars. In those times that was a lot, so it was very valuable", said Mrs. Hondoe (80) from Nickerie.

The by-products of rice production, such as husks, bran and broken grains were and still are used as fodder. Husked padi was fed to chicken and ducks. The milky juice squeezed from unripe rice panicles was said to be very nutritious for song birds, popular pets in many Surinamese households. According to 
SNRI/ADRON (2020), their experimental fields were often raided for young inflorescences by songbird traders. Pig feed consisted of husked padi, ground rice flour, waste material and broken grains. Leftover cooked rice was fed to the dogs. Farmers warned not to feed rice products to cows, as this harmed their stomachs. Bullocks were important as draft animal for plowing in traditional rice cultivation. While most people used the same rice variety for human and animal consumption, others cultivated short grain varieties for fodder and kept the long grain varieties for their own consumption or for sale. Short grain varieties did not sell for a good price, but had a higher yield per plant, which made it favorable for feeding livestock. All parts of the rice plant were put to something useful in the past. Mrs. Ramadin (71) from Nickerie recalled that when she was young the rice straw was used to construct roofs and walls of the little huts in which people lived.

After the modernization of the rice farming, many traditional Hindustani rice farmers could not afford the investments in machinery and were unable to compete with the large-scale producers. They sold their plot of land and moved to the city, where their children enjoyed better and longer schooling than their parents and grandparents. The highly educated new generation was eager to find better paid employment outside agriculture, and after Suriname's independence in 1975, many of them migrated to the Netherlands. Those traditional farmers who also grew vegetables and fruits decided to abandon rice, since they could make more profit with garden produce. The remaining small-scale rice farmers currently all use tractors and other machinery, but they can still hardly compete with large-scale rice producers. According to $\mathrm{Mr}$. Harimandan, chairman of the Surinamese padi farmers association (SPBA), Guyana is currently taking over the rice market. Many rice farmers search for better job opportunities to escape the financial risks that they face. The plummeting market prices for padi lead to a rapid decline in the number of small farmers and a decreasing quality of the product. Also, the lack of maintenance of roads and draining channels by the municipalities makes access to rice fields difficult, and contaminated water is not being refreshed (Gajadien-Bhagwat 2018).

While the modern rice farms expanded, some Hindustani smallholders continued with traditional rice production until they became too old and there was nobody left or willing to help them on their fields. Several elders we interviewed would have loved to maintain their rice fields but were unable to do so. Mrs. Bhoelai (62) from Houttuin, now a vegetable vendor at the Central Market in Paramaribo, explained: "We became too old and our children did not want to help us, as they found it hard and dirty work. I would have liked to continue [rice cultivation], since I was brought up with it and was used to it". Thinking of their farming days and their own rice fields, they felt a sense of happiness and pride. "My ancestors did it this way [by hand], I had their blessings if I also did it like that", explained Mrs. Jambadjan-Bhawari (88) from Nickerie. Once their children moved out of the house, the need to grow rice for home consumption also disappeared. The few small to middle-scale commercial rice farmers that remained active said they were 'born in the rice business'. Their fathers or grandfathers had invested in good farmland and machinery and they felt that if they would quit rice farming, these investments would have been lost. Mr. Soewad (40) a small rice farmer in Nickerie, spent his spare time working on his rice field, when he was free from his regular job as a taxi driver. "For me, rice farming is a hobby. I love doing it, it makes me feel relaxed. I took over the land and machines from my father, so it's in my blood, I must do it". For both the 
current and former farmers we interviewed, rice cultivation was more than a cheap way of obtaining food or a necessary job. It was also a source of pride and joy and a way of honoring and being spiritually blessed by their forefathers (Fig. 5A).

Traditional farming methods

\section{Field preparation and sowing}

Traditional rice farmers first weeded the field by hand with a machete, and then often put the field under water for three weeks, so the rotting weeds would act as a natural fertilizer. Sometimes ashes, cow dung or the remains of the harvested rice plants were added to the weeds and mixed with the clay as fertilizer before sowing. The majority of the 30 (former) rice farmers did not used any fertilizer, as this was not necessary since they only planted padi once or twice a year and the soil had sufficient time to 'rest'. In modern mechanical rice cultivation, fertilizer allows for almost continuous cultivation.

In the past, after weeding, the field was plowed by two bullocks, using a wooden plow ('harr'), as described by Stahel (1933). Puddling, crumbling and levelling of the soil, was done with plank attached to a yoke and drawn by bullocks (Fig. 5B). Pieces of old machetes were attached to the plank. One of our informants, an antiquarian, owned several of these wooden tools.

Sowing was done during 'pagya', the moment just before the large rainy season started in March. One method was to first sow the padi in a small section of the rice field, and cover the seeds with dry grass to protect them against the sun and birds. After six weeks, the women would plant the small seedlings, known as 'bibit', in the large field in $4 \mathrm{~cm}$ deep holes made with a rice planting stick ('khuti', Fig. 6). In softer soil, these holes were made by hand. Each bundle of bibit was placed on a fixed distance of c. 30 $\mathrm{cm}$ apart. This technique was especially used when farmers were growing different rice varieties at the same time. Another method was to sow eight to ten seeds directly in holes made with the planting stick on fixed distances in the field. The seeds were covered with soil and germinated when the first rains fell. A third method was direct seeding. A modern rice farmer (40) in Nickerie hired 15 men from his neighborhood to help him sow his two hectares. Since 1963, large-scale rice farmers switched to sowing, fertilizing and spraying pesticides with small aircrafts.

\section{Weeding and harvesting}

Three months after sowing, the rice plants started to flower. Sometimes it was needed to supply extra water to the rice field in this period, or to throw cow dung by hand to fertilize the soil if the plants turned pale. This was also the moment to weed the imposters growing between the rice plants. Mrs. Hondoe (80) from Nickerie distinguished different species of weeds, which carried names like 'Djoesa' and 'Bokmala', but these Sarnami names have not yet been connected to herbarium specimens and identified species. Towards the end of August, at the beginning of the long dry season, some six months after sowing, the rice plants turned dry and brown and were ready for harvest. 
Cutting the ripe panicles was done by hand with two different tools. In the Commewijne, where Hindostani and Javanese farmers lived close to each other, rice farmers preferred the 'ani ani', a traditional Javanese harvesting knife. This knife, also described by Stahel (1933) was handy to cut lodging varieties (Fig. 7A). The 'haswa', a serrated sickle-shaped grass knife that originated from India, was used for the non-lodging varieties in Commewijne and for all varieties elsewhere (Fig. 7B). Several interviewees still kept these traditional tools at home, and haswas are still used in Suriname to cut weeds in the yard. Former rice farmer Mrs. Tjirondjie (79) from Orleanakreek (Commewijne) used the ani ani to harvest the lodging varieties Champochino, Rexora and Mursila; while she took the haswa to harvest Mutmuria, Dima and Patarka. Rice plants were not uprooted from the field, as Mrs. Ramadin (71) from Nickerie, remembered: "The $30 \mathrm{~cm}$ high rice straw would remain on the field, and some varieties would sprout again. These would remain shorter and flowered quickly". Machetes were hardly used for harvesting rice, as the panicles needed to be cut carefully, to prevent damage to the other crops planted in between the rice, such as watermelons and black-eyed peas.

\section{Threshing, milling and winnowing}

Immediately after harvesting, the rice panicles were piled up to dry in front of the house in a pyramidshaped mount (Fig. 8A). The panicles needed to dry properly to prevent rotting during storage. Once dry, the panicles were threshed, by hitting the pile of rice bundles with a stick to loosen the seeds from the panicles ('dhan pakhèl'). Another threshing method was hand-beating the bundles over a wooden table with spaces between the planks ('dhanpietè'), through which the separated grains would fall on a canvas sheet placed underneath (Stahel 1933; Potter 1998). In a third threshing method ('astingai') the bundles were spread out on burlap sacks, and one or two bullocks were led to walk over it to separate the grains. A child would ride the animals or a farmer walked behind them to prevent them from going astray or eat the padi. The threshed rice would be stored in a wooden shed.

Before consumption, the rice had to be milled (dehusked), which was done manually by mortar and pestle. To separate the rice grains from the husks, a triangular winnowing fan ('soep') was used that was woven from bamboo leaves (Fig. 8B), which was similarly shaped as traditional fans from the Indian Bihar region, where much of the indentured laborers originally came from (Fig. 8C). With a particular shaking and throwing technique, the empty husks and rice bran would blow away in the wind, while the milled rice would remain in the soep. Manual dehusking was very labor intensive, so when rice hulling machines became available, all rice farmers abandoned the mortar and pestle. To make sure the grains were perfectly dry before entering the rice mill, farmers spread out their padi on canvas or plastic sheets in front of the milling company. Every hour they turned the padi over by walking through it barefoot in a shoveling way, a technique that is still practiced today, including the use of a traditional wooden rake (https://www.youtube.com/watch?v=qA3f9BABXvA\&t=133s).

\section{Pests, diseases and 'rice medicines'}

Chemical pesticides were not commonly used during manual rice farming, as 'it was not necessary because farmlands were smaller and healthier'. A few farmers used homemade 'medicines', like Mrs. 
Sewbaran (90) from Nickerie, who dissolved powdered soap in water and sprinkled the mixture by hand from a bowl on the rice plants. This method was said to be effective against seed bugs, known as 'ghanie' or 'gaudi': $1 \mathrm{~cm}$-long, green or brown insects that excreted a foul-smelling liquid, and pierced through the husks to suck out the immature grains. Former rice farmer Mr. Mahabier (85) from Commewijne obtained his insecticides from the Ministry of Agriculture, and wrapped the powder in a piece of cloth and hung this in a sock attached to a stick planted in his field. The three participants who were still involved in small-scale (mechanical) rice cultivation all used chemical pesticides, as they 'were unable to cultivate rice without them'. They drained their rice fields as soon as possible after sowing or planting the padi, and also used biological control agents, but no further details were provided. Weevils, known as 'padi lice' or 'ghoon', could become a pest during storage, especially when the padi was not dry enough or kept too long in a place where old or moist rice bags were lying around. The black weevils also affected other agricultural produce like peas, wheat flour and garlic.

Three interviewees complained about snails that lived in the rice swamps and ate the roots and young seedlings. These snails (Pomacea dolioides) still form a plague in large-scale rice cultivation and are currently fought with fentin acetate of metaldehyde (SNRI/ADRON, 2018). Former rice farmer Mrs. Oemawaty (77) from Nickerie said the snails also had a positive side: they were eaten by Javanese and Guyanese people, as they believed they were "good for your back". Birds were a major nuisance during the harvest period, as thousands of 'rice putters' (Molothrus bonariensis) would land on the fields and eat the ripe padi. People tried to chase them away with scarecrows. Mice and opossums damaged the rice plants and made nests and holes in the fields. Mrs. Oemawaty (77) remembered that people's feet would turn yellow because of a fungal infection caused by walking for prolonged periods in the rice swamps: "We called this 'murcha pakdi', and treated it with lime juice. Limes were also used to scrub off leeches, which were abundant in the submerged fields".

Animals in the rice fields

Some animals that were attracted to the rice fields were seen as positive. A variety of fish species lived in the wet rice fields and provided food, such as 'kwikwi' (Hoplosternum littorale), 'krobia' (Krobia cichlid), 'pataka' (Hoplias malabaricus), 'datrafisi' (Geophagus surinamensis) and 'walapa' (Erythrinus erythrinus). The larger irrigation canals housed capybaras ('kapoea', Hydrochoerus hydrochaeris), which were praised for their delicious meat. Snakes were considered a big safety risk in the rice fields. The most poisonous was the 'labaria' (Bothrops atrox), which was first tolerated to combat rats, but started reproducing rapidly as it had no natural enemies. Mrs. Tjirondjie (79) from Orleanakreek said that the 'makka' (Lachesis muta muta) was also a very dangerous snake, while the rattlesnake ('saka-sneki' or 'ghoon ghoona', Crotalus durissus) did not bite often but warned you about its presence by rattling with its tail. The end of the rattlesnake tail was used as protection against maleficent spirits. Three interviewees mentioned a measure to prevent snake bites by drinking a 'koti' (litt. 'to cut') to protect against a dark spell. The (sneki) koti was an herbal drink containing the leaves of 'sneki wiri' (snake weed, Eryngium foetidum L.), 'mope' seeds (Spondias mombin L.), pineapple and parts of snakes soaked in rum. Hindustani farmers obtained the mixture from Maroons living in the interior. According to Mrs. Sewbaran (90, Nickerie) you were not 
allowed to kill a snake after drinking the koti, otherwise it would not work anymore. Mrs. Ramadin (71, Nickerie) had seen a priest giving people injections with an unknown substance that would protect them against snakebites. Her husband (74) did not believe in these ritual preventions: "If I saw a snake, I would kill it. Even though it is a holy animal in Hinduism, in order to protect ourselves we are allowed to kill it." When bitten by a snake some people would consult to a doctor, while others relied on alternative healing methods. Six of the interviewees referred to a black stone from India that was used as a snakebite remedy. Mrs. Hondoe (80, Nickerie): "I never saw it myself, but I heard about it. This black stone was called 'jahar mohra', and you had to search someone who had it. The $1 \times 3 \mathrm{~cm}$ black stone would be tied on the bitemark to 'suck out' the venom. Sometimes a mantra would be said while placing the stone. Once all the venom was out, the stone would fall off by itself and could be reused after soaking it with milk".

Gender aspects of rice cultivation

In traditional rice farming, there was a division of labour between gender and age groups. Overall, men carried out the tasks that required intensive physical strength: sowing the padi in the submerged clay soils, plowing the fields with bullocks, threshing the panicles and using heavy tools. Mrs. Ghowrising (61) from Utrecht, the Netherlands: "women planted the bibit and weeded the fields, but during the harvesting period, many hands were needed and entire families worked together". Women generally worked on the rice fields between $7 \mathrm{am}$ and $5 \mathrm{pm}$, while their oldest daughter or the grandparents would take care of the smaller children. Former rice farmer Mrs. Hondoe (80) explained: "Every family had many children. My family had eight, and my aunt had 12 . We were neighbors, so we were very close and lived and ate together on a daily basis. As a woman you raised a total of almost 22 children from the whole family: your own, those of your brothers and those of your husband's previous wife".

Most children began helping in the rice fields at the age of 14 , starting with light tasks, like carrying the harvested panicles out of the field. From 1878 onwards children of immigrants were obliged to attend school from the age of seven to 12 , but many of them skipped classes during the busy planting and harvesting periods. "Normally, children were only allowed to help when they were finished with their school and homework", said Mrs. Oemawaty (77). Girls were expected to work on the rice fields after they had their first menstruation, and were considered women from that age. However, during their period, females were not allowed to work on the fields or touch any crops and fruit trees, as people believed that this would cause the harvest to fail. In most households, menstruating women were not allowed to cook or even touch conserved provisions, as this would spoil the food. People also helped on rice fields of community members. Instead of paying each other, people exchanged their time and services. "When you had 25 people working on your rice field that meant you'd be working for a total of 25 days for the people that helped you. This was a common practice among both Hindostani and Javanese farmers, known as 'ikta' in Sarnami and 'samhatan' in Javanese, both meaning 'unity', explained Mr. Harimandan (78), chairman of the Surinamese padi farmers association. 
The clothing worn on the rice fields differed between genders. To protect themselves from the burning sun, everyone wore long sleeves. Men wore a hat if they could afford it and otherwise a cap, while women wore a headkerchief. They walked barefoot, as footwear was easily lost in the thick mud. "Most people did not even possess shoes back then, and it was also believed that walking barefoot was healthy, as it massaged your body and helped against diseases", remembered bailiff and antiquarian Mr. Dwarka (61) from Nickerie. At that time, the women often made their own clothes instead of buying them in a store. The dresses and skirts were sewed in the evenings, after the other chores were finished. Clothes were often made of 'samberi', a plain denim-like fabric. Mrs. Hondoe (80) remembered that the women were quite ingenious with the available materials: five holes in a pair of socks would serve as gloves, needed when working with the haswa. "We wore the same clothes every day. As women we were not allowed to wear pants, so we tied up our skirts when working in the swamp. In the evening we had to wash the clothes, as we had to put them on again in the morning. If they had not dried overnight, we hung our clothes over the stove when we cooked breakfast in the morning." Mrs. Ramadin (71, from Nickerie) explained how women protected their legs as they were not allowed to wear pants: "We wore thigh-high 'socks' with elastic stitching to protect against the sharp leaves of the rice plants, so we could wear our skirt or dress over them." Men wore a type of sarong known as 'dhoti', a white sheet wrapped around the legs, the type that Hindu priest still wear today.

Rice in rituals and religion

Rice has played and still plays an important role in Hindu rituals and religious practices. Twelve of our interviewees were Hindu, one was Muslim and five were Christian. In the past, Hindustani farmers carried out a ritual to ensure a prosperous harvest by gathering a bunch of unripe rice culms, removing the young grains by hand and cook them with milk, sugar and ghee (clarified butter). They prayed on the rice field and went home to consume the blessed sweet rice dish ('persawt'). All interviewees agreed that the rice used in Hindu rituals did not necessarily had to be self-cultivated. In former times people used their homegrown padi, but now they bought rice for their rituals from farmers, on the market or in ritual stores.

Rice symbolizes prosperity, welfare and fertility in wedding rituals, as a good harvest means lots of rice, food and income. A Hindu wedding ceremony is held in a small temple ('maaro'), in which different rituals are carried out. Husked rice is fried like popcorn and stirred with a broom made of coconut leaf midribs ('printa sibi') in a pan ('karhaija') over a wood fire by the aunts of the bride and groom. It is important that the padi is dry, otherwise it will not pop. This ritual food is known as 'laawa bhoedjaawe' (puffed rice), and for this reason husked rice is sold in ritual Hindu shops in the Hague. During wedding traditions of the Sanatana Dharma movement, the bride ('dulhin') and groom ('dulha') smear cow dung in a certain pattern in an earthenware, brass or copper bowl ('talsa' or 'lota') when they arrive in the bridal temple. The bowl is decorated by pressing padi in rows in the cow dung. When the bride leaves her parental home and is symbolically given away to the husband's family, her mother throws padi on her from behind to ensure the newlyweds stay happy. During funerals, padi is scattered on a wooden board, covered with sand and then laid down in running water. Most wedding and funeral rituals are led by a pandit. Hindu's from the 
Aria Dewaker movement give the pandit a 10 or 15-kilo bag of milled rice after the rituals are performed, while the Sanatana Dharma normally pay the pandit a considerable sum of money.

To celebrate Diwali, the festival of light, Surinamese Hindus harvested some handfuls of rice from their field - whether it was ripe or not - and cooked the sweet rice dish 'mita bhaat' with sugar and milk. In some religious ceremonies, padi was offered in running water. In the past, people also made 'rice roti': a flat bread made from flour of uncooked, pounded rice that was sieved, mixed with salt and baking soda and pressed flat with the hands. The dough was baked in a hot pan with oil and turned until it was baked on both sides. Because of the large-scale import of wheat flour, the laborious rice roti is not often made anymore.

Spiritual beliefs

Malicious spirits are considered to hide in the rice fields and nearby forests. Mrs. Karmale (66) from Mariënburg carried garlic or a pin with her when working on her rice field for protection. It was not a common practice to work on the rice field in the evening. Former rice farmer Mrs. Hondoe: 'After six o' clock you cannot work on field. Hindustani believe that everything is resting and the plants are sleeping, so you cannot interrupt them. Dark devilish things wake up after that time. There used to be no light after six, so it was dark and people were afraid of everything and went home." The Sewbaran family remembered that some people used a 'tapu', a powerful amulet to protect themselves against evil powers. "When using this aid, it was not permitted to look at a pregnant woman, as she would have a miscarriage." Mrs. Karmale also remembered rituals to protect babies and mothers, such as a pin attached above the front door or a drink that contained shavings of deer antlers.

Former rice farmer Mrs. Bhoelai (62) from Houttuin explained: "On almost every property, there is a part that is said to be haunted, because long ago it used to be an Amerindian burial place. If you disrespect the soil there, for instance by washing dirty clothes, this could lead to misfortune, miscarriage or even the death of yourself or a loved one. I don't believe in it, but my mother-in-law does." Younger generations said not to not believe anymore in these 'spuku tories' (spooky stories), but were still fascinated by them, while older generations either refused to talk about them or denied they knew anything about them. Still, some people would not walk on certain parts of their property. Both Hindustani and Maroon farmers believed that dark-husked rice varieties would have lighter husks when they were sown during full moon, and some planted darker rice varieties on purpose during this period.

\section{Discussion}

Loss and exchange of traditional rice varieties and cultivars

The current Hindostani smallholders we interviewed mostly grew modern rice cultivars, developed after 2000. Occasionally, old cultivars from the 1950s were grown for fodder. They were heavily mixed with rice weeds and weedy rice, and sometimes sold for an inflated price as 'ritual rice' in the Netherlands. The original landraces, brought along from India by the indentured laborers at the end of the 19th century, are 
no longer grown in coastal Suriname. Some of these ancient varieties, however, seem to have been exchanged with Maroons in the past, and may still survive on their rice fields carrying names like Koelie aleisi, Mbotombolia, Patalika and Watralanti. This historic rice exchange between Hindostani and Maroon farmers could be confirmed by additional collection of herbarium specimens from Maroon rice fields and molecular research, in which the DNA of 'coolie rice' types is compared to that of historic herbarium samples and existing genomic data on East Indian varieties kept in germplasm banks. This can shed light on the geographic origin of these Asian rice cultivars and fill gaps in the history and provenance of Indian contract laborers. This is not only relevant for the agricultural history of East Indians in Suriname, but also those in Guyana, who lost most of their traditional varieties already in the early 1900s (Potter 1998).

Recently, a single accession of Watralanti from the Marowijne area was shown to be genetically quite distant from traditional Maroon landraces, but quite similar to the SML cultivars Ciwini and Acorni, developed in the 1970s (Van Andel et al. 2019). This suggest that some of the 'coolie rice' grown by Maroons may descend from cultivars developed after the Green Revolution, instead of from traditional Indian landraces. Aucan farmers in Commewijne, who were in regular contact with Hindostani farmers, also grew rice cultivars developed after 1950. Our research indicated that Hindostani and Javanese farmers also exchanged varieties in the past. Very little information exists on traditional rice cultivation by Javanese farmers in Suriname today (Heilbron 2012). Molecular comparison of the many Javanese rice accessions from the 1930s in the Naturalis collection and landraces currently grown in Suriname could also reveal hidden information on the migration of Javanese people, and the adaptation or their crops to a new environment.

Traditional practices

Hindostani smallholders have largely lost their traditional rice cultivation practices. Bullocks have been replaced by tractors and the fierce competition by large-scale rice producers will probably soon lead to the abandonment of all small-scale rice production by Hindostani farmers. The wooden farm equipment and processing tools, described in detail by Stahel (1933), were still encountered in people's homes, antique shops and the Lalla Rookh museum. Most of our participants still retained pleasant memories of the manual planting, harvesting, and processing of rice, as well as the many gender-based practices and beliefs associated with the cultivation of the crop. Potter (1998) reported similar stories among smallholders in Guyana: in spite of their poverty and back-breaking work, people said they had been happy as they were self-sufficient in food and had a strong sense of community, with people helping each other. Although rice still plays an important role in Hindu religion, rituals can now be performed with shopbought rice instead of home-grown padi. The oral history of former rice farmers, however, should be better preserved than it is today. Personal stories and traditional rice varieties (if found on Maroon fields) could play a role in museum settings as living vehicles for memories of the descendants of Asian contract labourers in Suriname and Guyana.

\section{Declarations}


We would like to thank Jerry Tjoe Awie and Sheshadhary Raghoedatpanday of the SNRI/ADRON for their collaboration during fieldwork, Micha de Boer for his photographs of rice grains and Jermain Keizer for his help during fieldwork in JawJaw. We are grateful to: Jhingoerie Wierin; Soerin Takoersin, Gadhjoe Chitrawatie, Bhoelai Gisila, Cicialia Rashpati Chotkanoe-Jhinkoe, Chanta Ghowrising, Sitaram Soewad, Sheshadhary Raghoedatpanday, Ramadhin, Oemrauw Harimandan, Gatham Dwarka, Datadin Hondoe, Nanda-Kamla Ramadin, Kali Ramnaik, Mr. Van Gooyer, Anita Rambalie, Chanderwatie Somaroe, Moenle Sewbaran, Tatwatie Nandelah, Anoeradj Sewbaran, Tricie, Lekhaam Mahabier, Boenakaba Andelia, Toly Ajafu, Karmen Baygadi, Agnes Bjoudia, Kenneth Pawirodimijo, Bimaldei Algoe-Chotoe, Nirmal Tjirondjie, Vera Bjoudia, Rosie Karmale, Mario Walter Soloman, Farida Seeda, Agnes Afonsoewa, Mirjam Mateda, Cleo Lodewijk, Emelientje Fonkel, 'oma Nana', Hirasing Oemawaty, Narain and Rohan for sharing their memories on rice cultivation.

\section{Funding}

This work was supported by Naturalis Biodiversity Center, the Van Eeden Fonds, the Alberta Mennega Stichting and the Leiden University Fund.

\section{Declaration of interest statement}

The authors declare that the research was conducted in the absence of any commercial or financial relationships that could be construed as a potential conflict of interest.

\section{References}

Anonymous (1938) Surinaams verslag 1936: Statistisch jaaroverzicht van Suriname over het jaar 1937. Algemeene Landsdrukkerij, 's-Gravenhage.

Baumgart IR, Hille Ris Lambers D, Khodabaks MR, Wildschut J (1998) Visit to rice growing sites on the upper Suriname river between Nieuw Aurora and Abenaston. SNRI/ADRON, Nickerie.

Boonacker J (1933) Hoe kan Suriname's landbouw tot ontwikkeling komen? NWIG 14:342-346. https://www.jstor.org/stable/41846465

Boonacker J, Drost AW (1907) Rijstcultuur. Inspectie van den Landbouw in West-Indië 8. HB Heyde, Paramaribo.

Brandon HG (1933) Proefneming voor machinale hoeverijstcultuur op de plantage Guadeloupe in Suriname in 1925-1926. NWIG 14:81-98. https://doi.org/10.1163/22134360-90001031

Codd LEW, Peterkin EM (1933) Rice in British Guiana, 1927-1932. Vol. 1. Rice bulletin, 1-38. British Guiana Department of Agriculture, Georgetown. 
De Wit TPM (1960) The Wageningen rice project in Suriname: A study on the development of a mechanized rice farming project in the wet tropics. Dissertation, Wageningen University.

Deb D (2019) Restoring Rice Biodiversity. Sci Am 321:54-61.

Debidien B (2020) Adron in financiële problemen. De Ware Tijd 19 August 2020.

http://www.dwtonline.com/laatste-nieuws/2020/08/19/adron-in-financiële-problemen/

Fokken M (2018) Beyond being koelies and kantráki: Constructing Hindostani identities in Suriname in the Era of Indenture, 1873-1921. Dissertation, Groningen University.

Gajadien-Bhagwat A (2018) SPBA: rijstsector staat op instorten. Dagblad Suriname 20 May 2018. https://www.dbsuriname.com/2018/05/20/spba-rijstsector-staat-op-instorten/

Gowricharn R (2013). Ethnogenesis: the case of British Indians in the Caribbean. Comp Stud Soc Hist 55:388-418.

Heilbron T (2012) Botanical relics of the plantations of Suriname. Disseration, University of Amsterdam.

Hoefte R (1998) In place of slavery: a social history of British Indian and Javanese laborers in Suriname. University Press of Florida, Gainesville.

Hua L, Wang DR, Tan L, et al (2015) LABA1, a domestication gene associated with long, barbed awns in wild rice. Plant Cell 27:1875-1888. doi: 10.1105/tpc.15.00260

IPBES (2019) Global assessment report on biodiversity and ecosystem services. United Nations and FAO, Rome.

Maat H (2001) Science cultivating practice: a history of agricultural science in the Netherlands and its colonies, 1863-1986. Kluwer Academic Publishers, Dordrecht.

Maat $\mathrm{H}$, Van Andel TR (2018) The history of the rice gene pool in Suriname: Circulations of rice and people from the eighteenth century until late twentieth century. Hist Agrar 75:69-91.

Mahabier E (2007) Rijstproductie Suriname goed om 1,25 miljoen mensen te voeden. Nickerie.net. http://www.nickerie.net/News2007/2006-11-07\%20-\%20dwt\%20-

Rijstproductie\%20Suriname\%20goed\%20om\%201.25\%20miljoen\%20mensen\%20te\%20voeden.htm

McCouch S (2004) Diversifying selection in plant breeding. PLoS Biol 2:e347.

Ostendorf FW (1962). Nuttige planten en sierplanten in Suriname. Bulletin 79. Landbouwproefstation in Suriname, Paramaribo.

Price S (1993) Co-wives and calabashes. University of Michigan Press, Ann Arbor. 
Potter L (1998) Breaking away from sugar? East Indians and the rice industry of Guyana, 1905-1940. Journal of South Asian Studies 21:s1:137-160.

Roosken E (2010) Caught between Christianization, assimilation and religious independency: The Hindustani community in Suriname. Dissertation, Erasmus University.

Sanderson AG (1962) The agricultural economy of Suriname (Dutch Guiana). US Department of Agriculture, Economic Research Service, Washington DC.

Sharif BM, Burgarella C, Cormier F et al (2020) Genome-wide genotyping elucidates the geographical diversification and dispersal of the polyploid and clonally propagated yam (Dioscorea alata L.). Ann Bot https://doi.org/10.1093/aob/mcaa122

SNRI/ADRON (2010) Jaarverslag 2009. SNRI/ADRON, Nickerie. http://www.adron.sr/files/2009--adronjaarverslag.pdf

SNRI/ADRON (2017) ADRON info: het gevolg van illegaal zaaizaad. ADRON Mediatheek. https://www.youtube.com/watch?v=y0553aDtt0g

SNRI/ADRON (2018) Slakken infofolder. SNRI/ADRON, Nickerie. http://snri-adron.com/downloads SNRI/ADRON (2020) Beschadiging proefplotjes SNRI/ADRON door zangvogelhouders. Facebook 26 February 2020. https://www.facebook.com/adron.sr/posts/2727452053959142.

Stahel G (1932) Rexora rijst. Suriname: koloniaal nieuws- en advertentieblad 97:2-3.

Stahel G (1933) De rijstcultuur in Suriname. Bulletin 2. Landbouwproefstation in Suriname 3, Paramaribo. Stahel G (1944) De nuttige planten van Suriname. Landbouwproefstation in Suriname 59, Paramaribo. Van Andel TR (2010) African rice (Oryza glaberrima Steud.): Lost crop of the enslaved Africans discovered in Suriname. Econ Bot 64:1-10.

Van Andel TR, Meyer RS, Aflitos SA et al (2016) Tracing ancestor rice of Suriname Maroons back to its African origin. Nature Plants 2:10.

Van Andel TR, Ruysschaert S (2011) Medicinale en rituele planten van Suriname. KIT Publishers, Amsterdam.

Van Andel TR, Veltman MA, Bertin A et al (2019) Hidden rice diversity in the Guianas. Front Plant Sci 10:1161.

Van Drent E (1908) Verslag van den waarn. Labouw-leeraar. In: van Hall CJJ (ed) Inspectie van den landbouw in West-Indië. Landbouwproefstation Suriname, Paramaribo, pp 39-50. 
Wang W, Mauleon R, Hu Z et al (2018) Genomic variation in 3,010 diverse accessions of Asian cultivated rice. Nature 557:43-49.

Williams RO, Williams Jr RO (1951) The useful and ornamental plants in Trinidad and Tobago. Department of Agriculture, Port of Spain.

Zeven AC (1998) Landraces: a review of definitions and classifications. Euphytica 104:127-139.

\section{Figures}
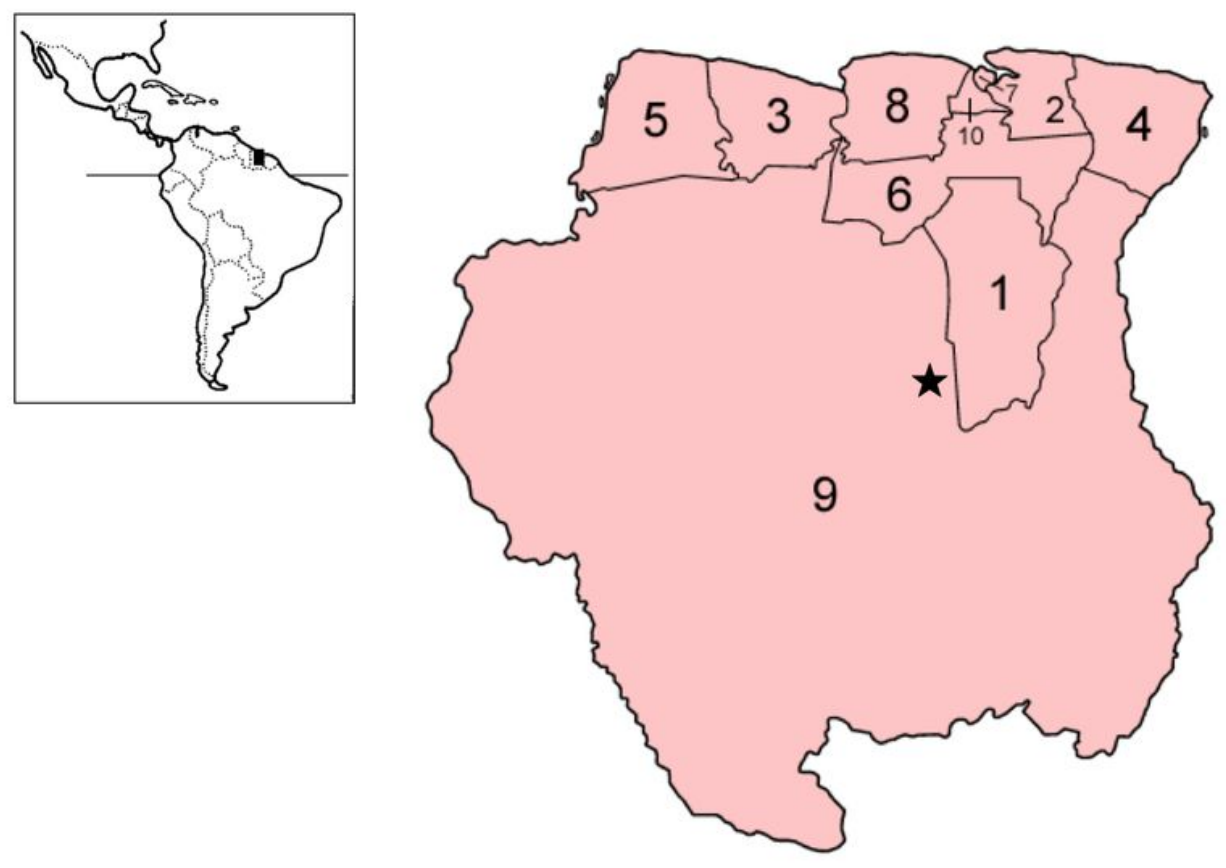

\section{Figure 1}

Location of Suriname and districts: 1. Brokopondo; 2. Commewijne; 3. Coronie; 4. Marowijne; 5. Nickerie; 6. Para; 7. Paramaribo; 8. Saramacca; 9 . Sipaliwini, 10. Wanica. $\otimes$ Jawjaw. Note: The designations employed and the presentation of the material on this map do not imply the expression of any opinion whatsoever on the part of Research Square concerning the legal status of any country, territory, city or area or of its authorities, or concerning the delimitation of its frontiers or boundaries. This map has been provided by the authors. 

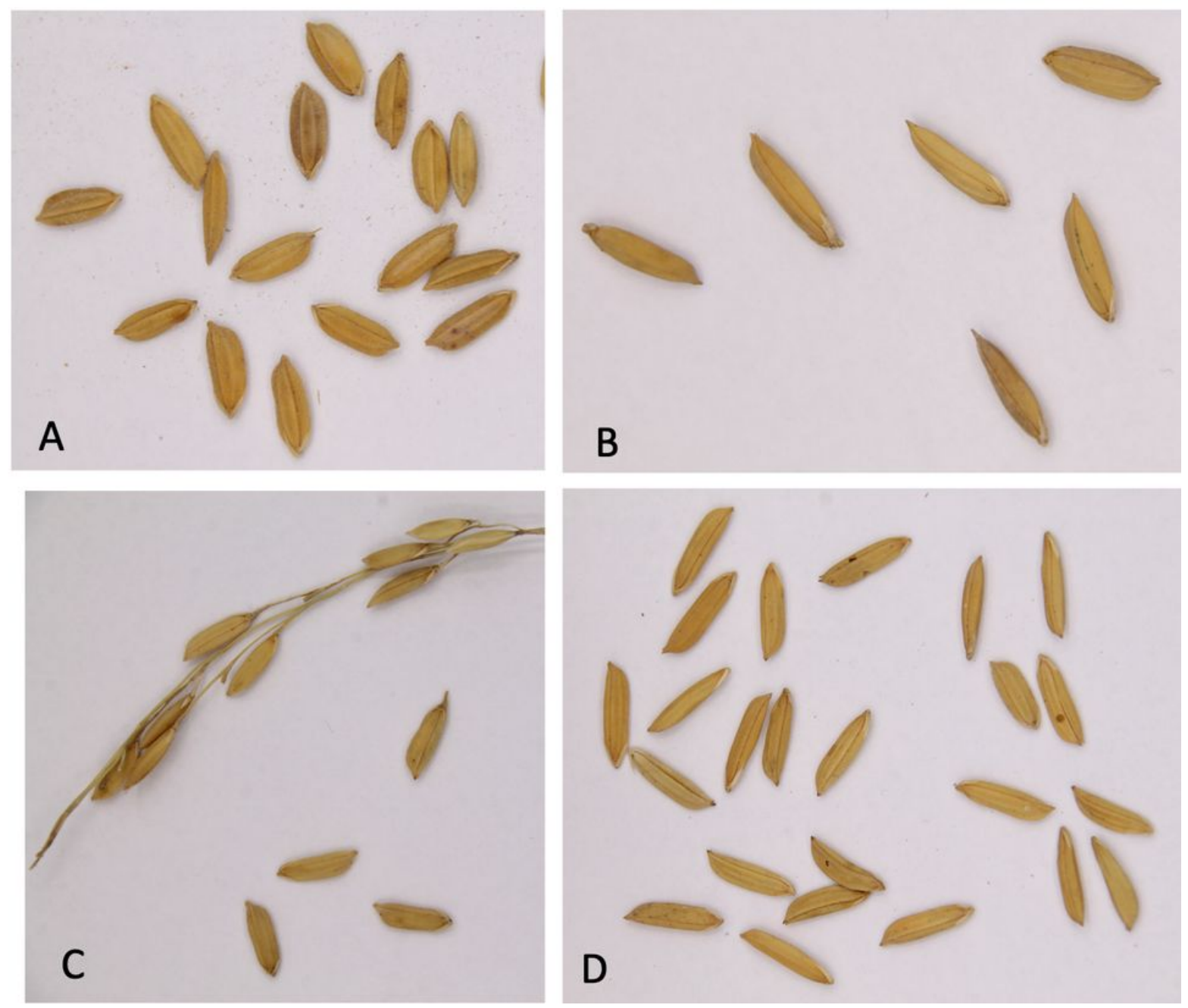

Figure 2

A Raymoen (MMR6) showing variability of grain sizes. 2 B White Sola (MMR11) grown by an Aucan farmer in Macreabo. 2 C. Dima (MMR18), collected in Marowijne, Km 47. 2 D. DDB2 (MMR5), grown in Saramacca. Pictures by Micha de Boer 


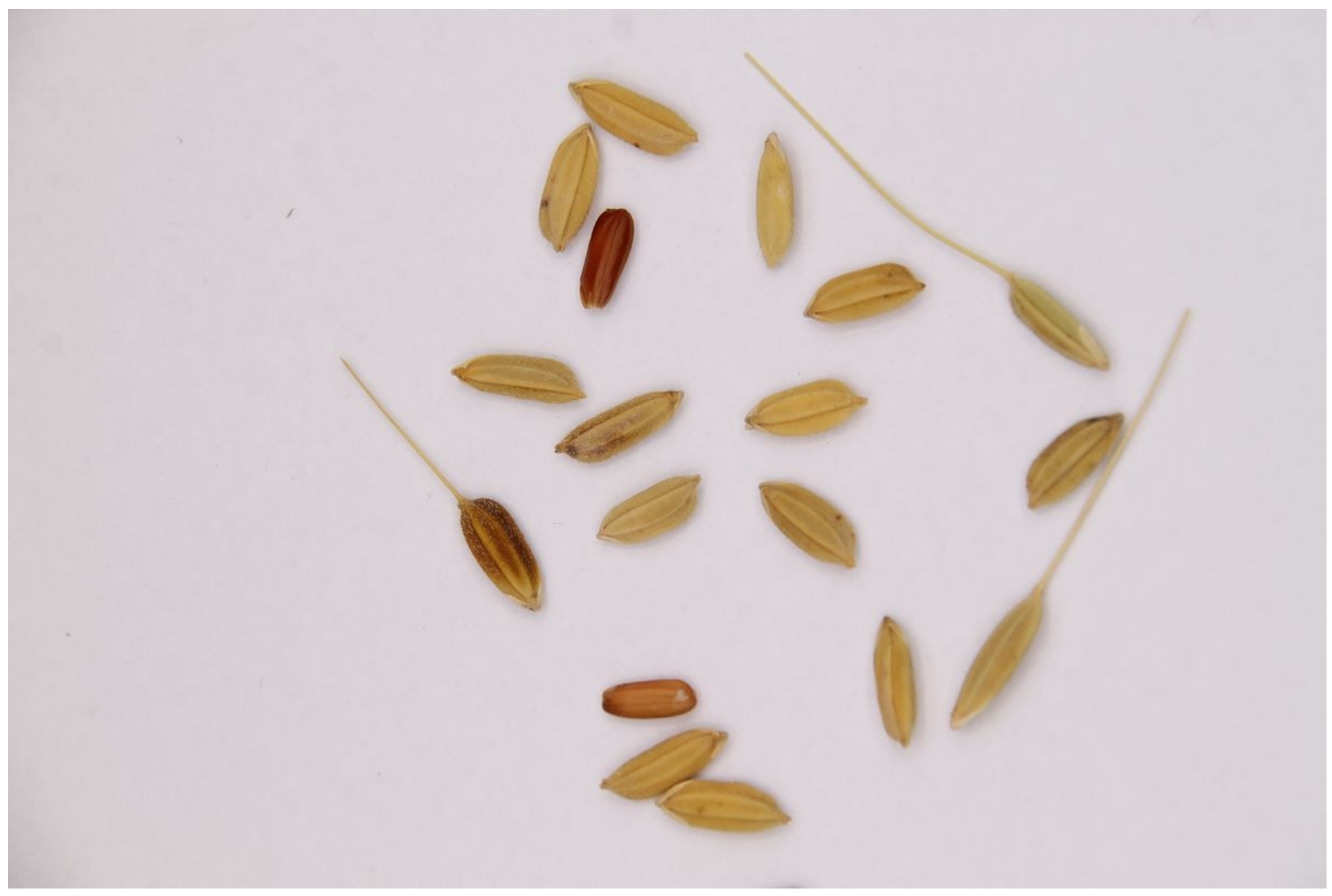

\section{Figure 3}

'Nickerie padi' fodder rice sample (MMR3) mixed with different types of weedy rice (awned and hairy husks, red seeds). Picture by Micha de Boer 

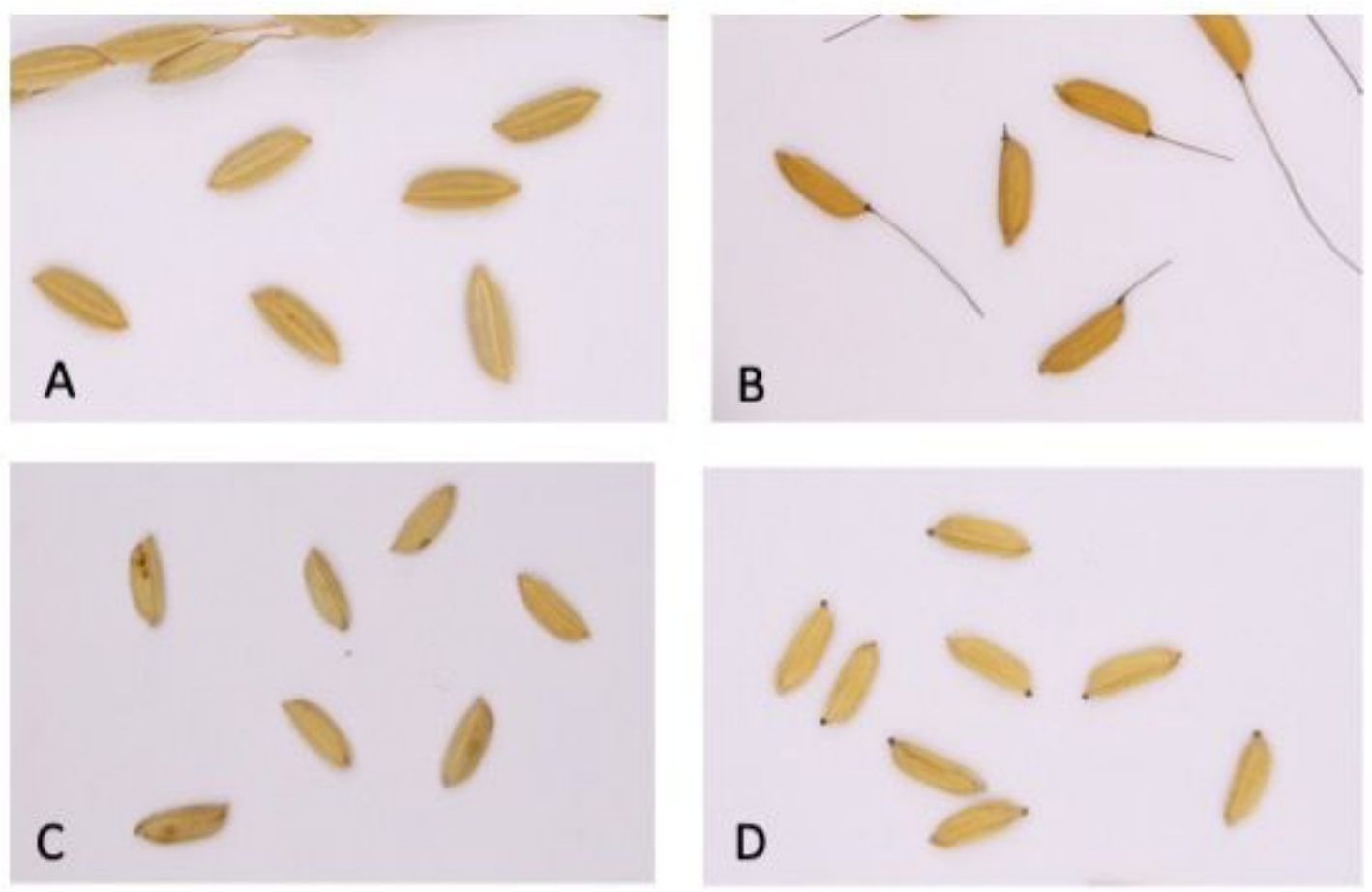

\section{Figure 4}

A Koelie aleisi with hairy husks (MMR31); 4 B Koelie aleisi with awns and glabrous, orange husks (MMR30); 4 C Koelie aleisi with glabrous, white husks (MMR29); 4 D Watralanti (MMR34). All varieties were grown by Saramaccan Maroons in Jawjaw. Pictures: Micha de Boer 


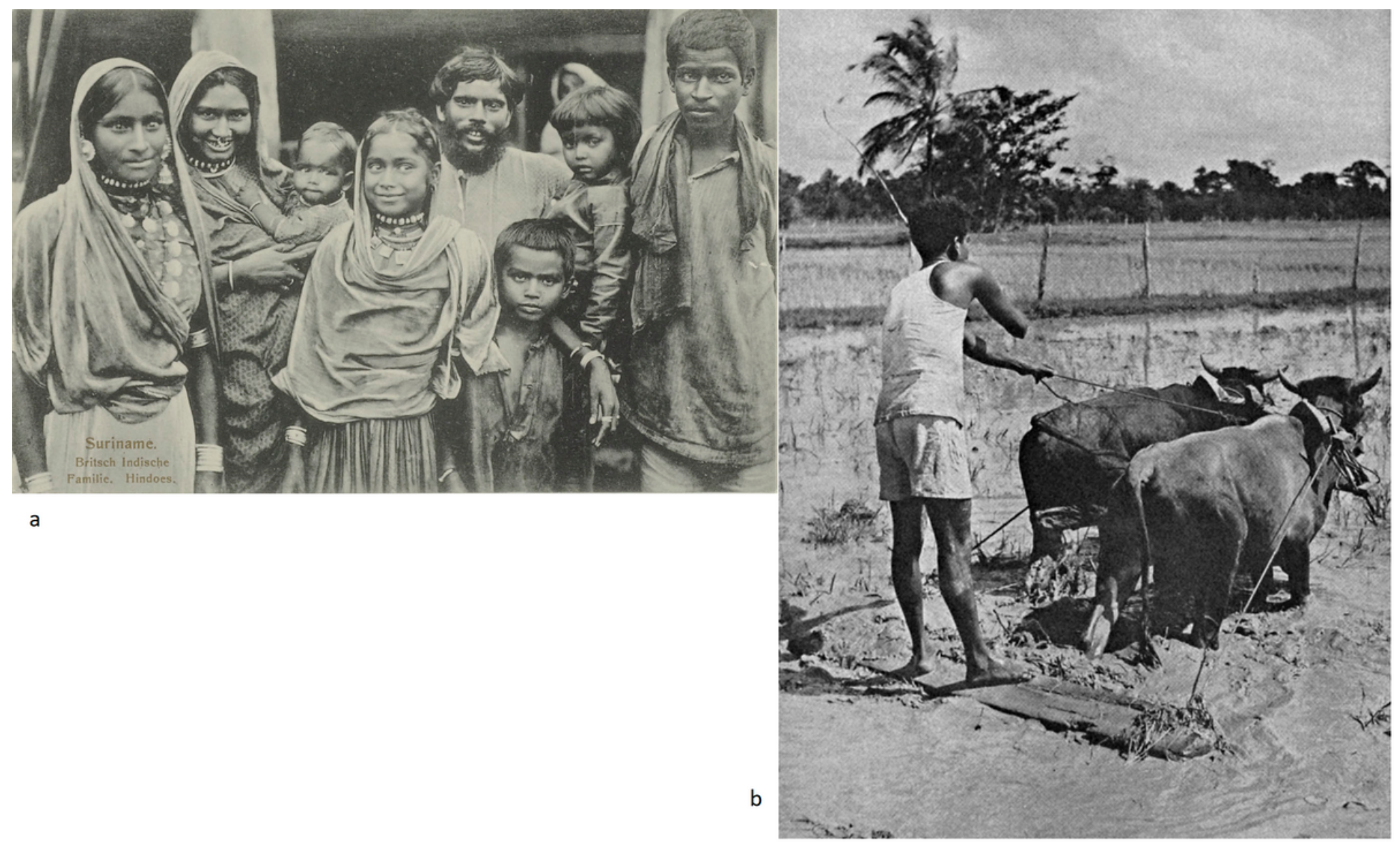

Figure 5

A First generation of Indian indentured laborers in Suriname (c. 1900): the forefathers of the current Hindustani rice farmers. Picture: Museum of World Cultures (1900-A296-51); 5 B Hindostani farmer levelling a rice field with two bullocks, Suriname (1905). Picture: University of Amsterdam special collections (URI01-2792H39PL122). 


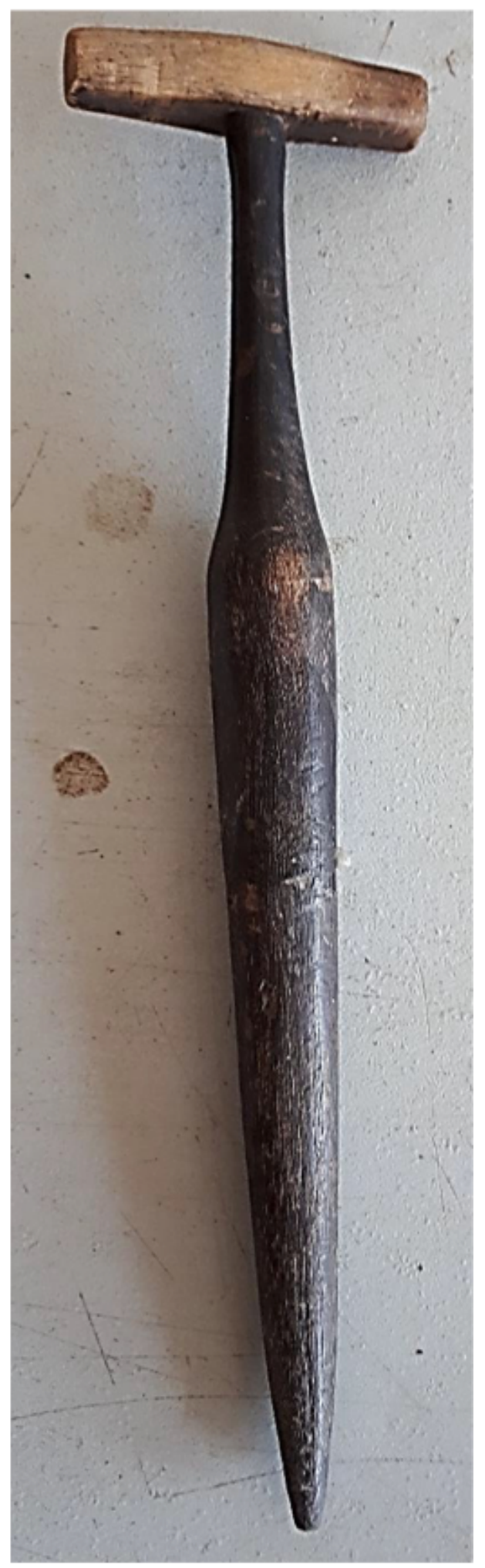

Figure 6

Traditional rice planting stick (kuthi) owned by antiquarian in Nickerie. Picture: Melissa Ramdayal. 


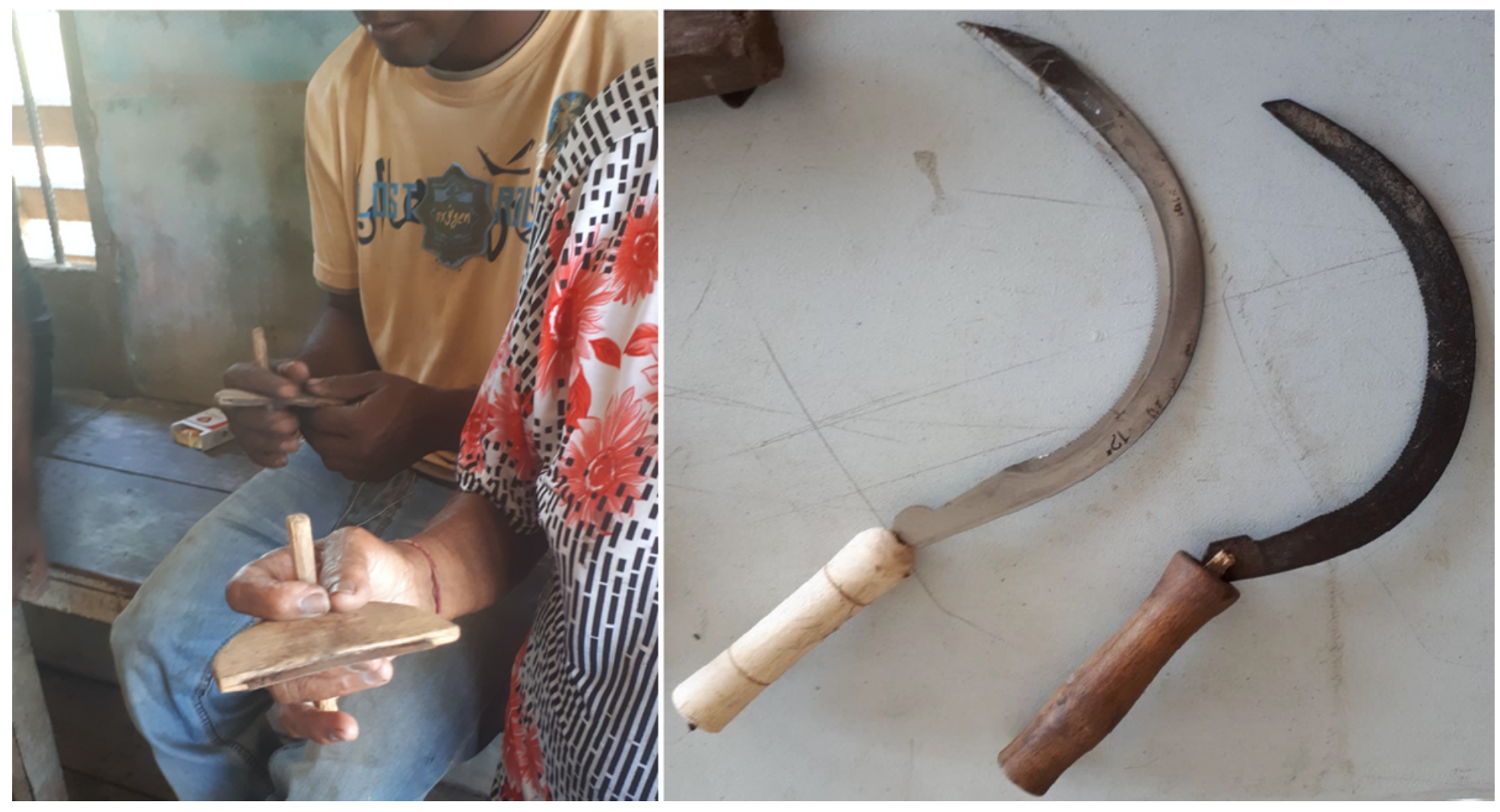

Figure 7

A Former rice farmers demonstrating how to hold the ani ani, a traditional Javanese harvesting knife. 7 B Modern (left) and antique (right) haswa. Pictures: Melissa Ramdayal 


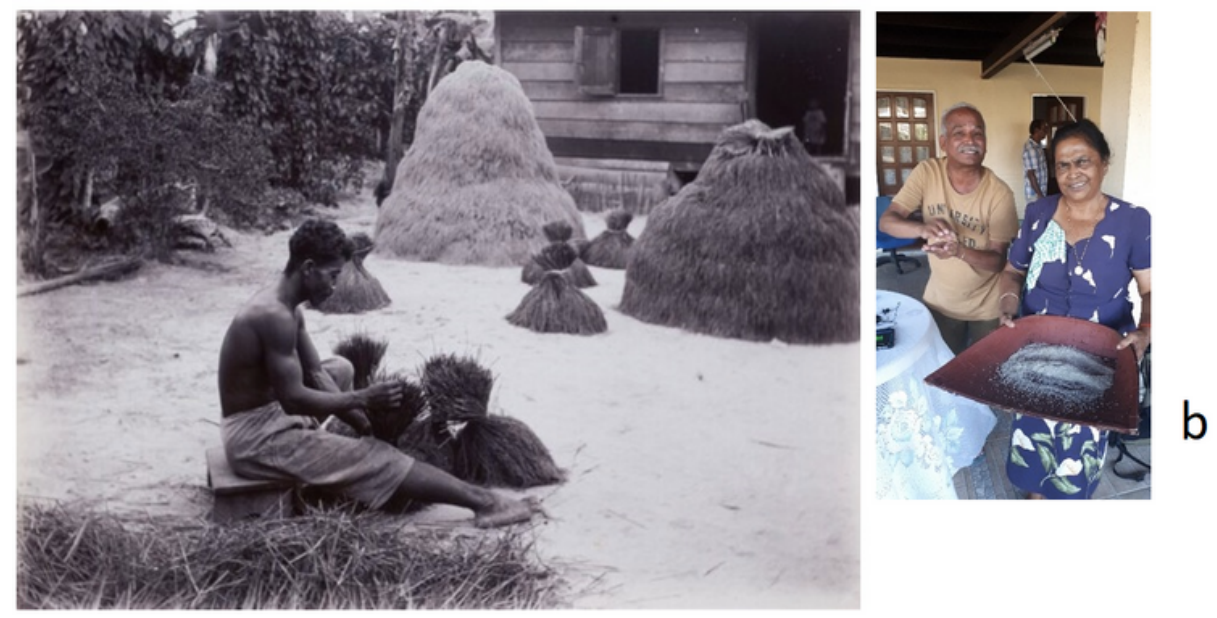

a

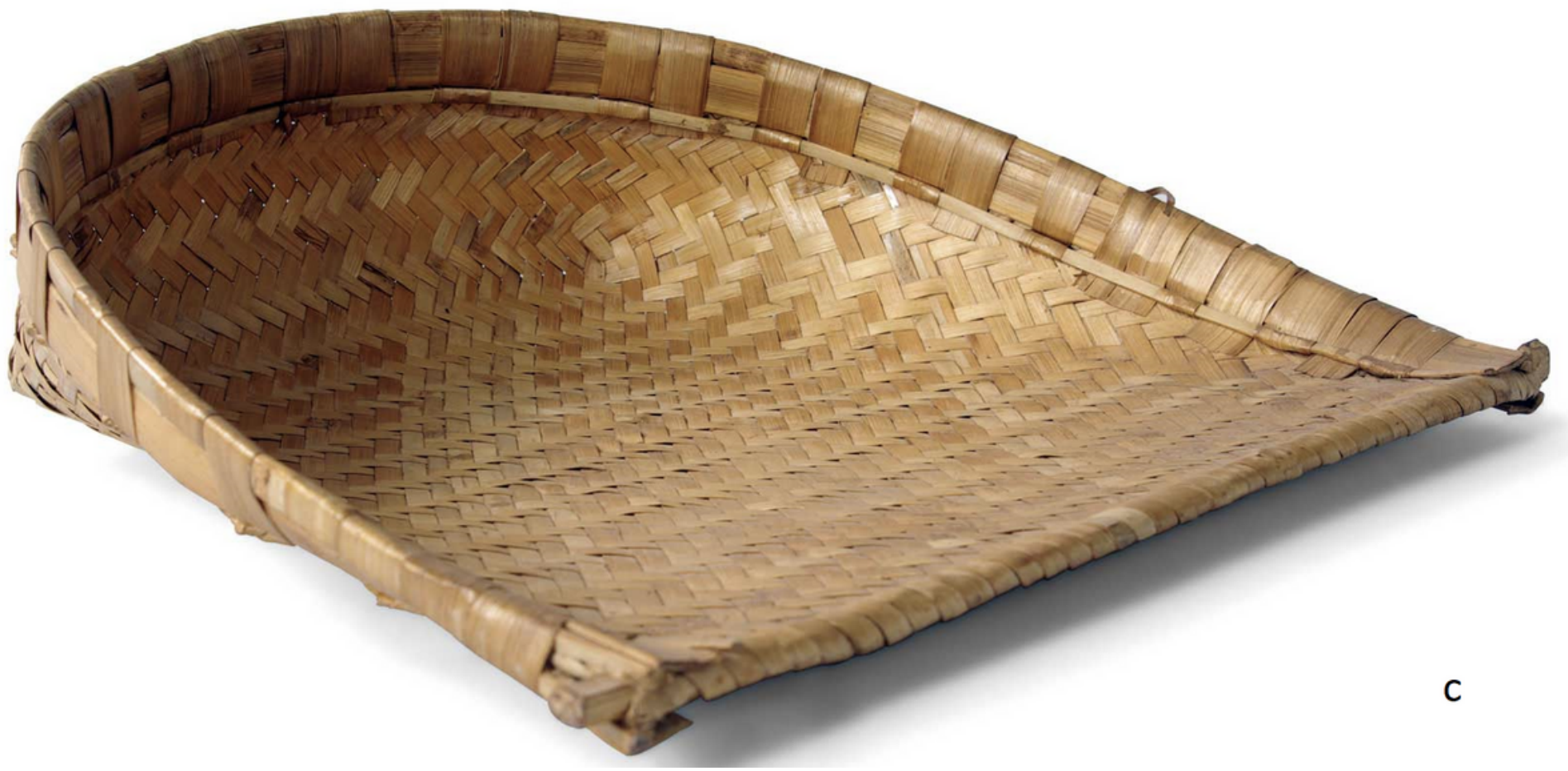

Figure 8

A Farmer tying bundles of harvested rice. The mounts of rice panicles are visible in the background, Suriname (c. 1920); 8 B Mrs. Ramadin from Nickerie showing a traditional winnowing fan ('soep'); 8 C Traditional Indian winnowing fan. Pictures: A. Museum of World Cultures (TM-60006030); B. Melissa Ramdayal, C. Odisha State Tribal Museum, Bhubaneshwar, India.

\section{Supplementary Files}

This is a list of supplementary files associated with this preprint. Click to download. 
- SupplTable1Historicvarieties.xlsx

- SupplTable2Questionnaire.docx

- SupplTable3Ricevarietiesmentionedduringinterviews.xIsx

- SupplTable4Sarnamiriceterms.xIsx 